\title{
REGULATORS OF IMMUNOLOGICAL RESPONSES IN THE CORNEA AND THE ANTERIOR CHAMBER OF THE EYE
}

\author{
MARTINE J. JAGER ${ }^{1}$, DALE S. GREGERSON ${ }^{2}$ and J. WAYNE STREILEIN ${ }^{3}$
}

\begin{abstract}
SUMMARY
Although the eye is considered to be immunologically privileged, this privilege is not absolute. This is well demonstrated by, for example, the fate of corneal transplantations. Clinical studies in man and experimental studies in animals have shown that survival of a corneal transplant depends on the local condition of the cornea and the anterior chamber of the eye. The presence of neovascularisation or Langerhans cells in the recipient cornea endangers the graft, while the intracorneal production of immunosuppressive factors may inhibit the development of rejection. The balance between suppressive and stimulatory factors determines whether a local immune response will develop.
\end{abstract}

Although the eye is considered to be immunologically privileged, this privilege is not absolute. The existence of immunological privilege of the eye was demonstrated by Medawar ${ }^{1}$ by placing tissues into the anterior chamber of the eye: grafts that would have been rejected when placed elsewhere, survived when put inside the eye. Immunological privilege does not occur only in the anterior chamber; its effect can also be recognised in the cornea. ${ }^{2,3}$ A lamellar corneal graft hardly ever undergoes rejection, and a perforating keratoplasty into a healthy recipient cornea will usually survive. Such a graft would easily be recognised and destroyed when placed on, for example, the skin. However, a corneal graft may also be rejected. Which factors determine what will happen?

Clinical studies in man and experimental studies in mice, rats and rabbits have shown that a wide variety of parameters influence the outcome of a corneal

From: ${ }^{1}$ Department of Ophthalmology, Academic Hospital Leiden, Leiden University, The Netherlands; ${ }^{2}$ Department of Ophthalmology, University of Minnesota, Minneapolis, USA; ${ }^{3}$ Schepens Eye Research Institute, Boston, Massachusetts, USA.

Correspondence to: Dr M. J. Jager, Department of Ophthalmology, Academic Hospital Leiden, PO Box 9600, 2300 RC Leiden, The Netherlands. Fax: 071-248222. transplant. Such parameters include the type of underlying disease, the presence of neovascularisation and Langerhans cells in the central cornea, inflammation of the anterior chamber and the size of the graft. ${ }^{3.5-7}$ It is clear from these clinical results that both the anterior chamber of the eye and the local condition of the cornea influence corneal graft survival. The same factors may play a role in the defence against infections, in which case an effective immune response is essential to get rid of the invading pathogen. However, the development of a massive immune response might at the same time severely damage the ocular tissues, and a good equilibrium between stimulation and inhibition of the immune response may be essential in preserving vision.

We will discuss the pathobiology of some factors involved in the local immune response in the cornea: (1) the influence of neovascularisation and Langerhans cells in the cornea on graft survival and viral infections; (2) the presence of immunosuppressive factors in the anterior chamber; and (3) the production of immunosuppressive factors by the cornea. We will discuss some in vitro tests that demonstrate that even a human cornea suffering from bullous keratopathy is still able to induce an immunosuppressive effect.

\section{NEOVASCULARIS ATION AND LANGERHANS CELLS IN THE CORNEA}

Studies on corneal graft survival have shown that the presence of vessels in the recipient cornea prior to transplantation is associated with a poor graft prognosis. Second and subsequent grafts carry a worse prognosis than primary grafts, and VölkerDieben ${ }^{8}$ elegantly demonstrated that the higher the number of previous grafts, the higher the percentage of corneas with significant vessel ingrowth. The relevance of vessel ingrowth had been demonstrated in one of the first studies on corneal transplantation in rabbits: Khodadoust and Silverstein ${ }^{9}$ showed that 
almost all grafts placed on a vascularised recipient cornea failed, while grafts placed on a non-vascularised recipient bed usually survived. Williams and Coster $^{10}$ set up a genetically well-defined system in the rat, and observed that following grafting into vascularised recipient corneas, rejection not only occurred more often, but also at an earlier time point. Vessels can probably be regarded as 'highways' for the influx of immunologically active cells, although an additive role in sensitisation cannot be excluded.

Vessels may also be an indicator for another essential factor, i.e. the presence of Langerhans cells (LCs). These antigen-presenting cells are absent from the centre of a normal, healthy cornea, but in diseases that are known to carry a poor graft prognosis the cornea contains large numbers of antigen-presenting cells prior to transplantation (see review ${ }^{11}$ ). Gillette et al. ${ }^{12}$ determined the number of LCs in various corneal diseases. Many LCs were seen in herpes simplex infection (300-500/ $\left.\mathrm{mm}^{2}\right)$ and keratitis $\left(200-400 / \mathrm{mm}^{2}\right)$, and low numbers were observed in Fuchs' endothelial decompensation $\left(0-100 / \mathrm{mm}^{2}\right)$ and keratoconus $\left(0-25 / \mathrm{mm}^{2}\right)$. The first two diseases carry a poor graft prognosis, the latter two a good prognosis. Corneas with secondary decompensation following cataract surgery carry intermediate numbers of LCs, ${ }^{13}$ and show intermediate graft survival.

LCs are antigen-presenting cells that are able to pick up foreign antigen and carry it to the lymphatic system. Although their exact route from the eye to the lymph node has yet to be elucidated, it is likely that immunisation against a graft occurs more frequently when the recipient cornea contains many LCs. The effect of the presence of LCs in the cornea has not only been suggested on the basis of circumstantial evidence but has also been demonstrated experimentally in an animal model. ${ }^{4,14}$ Injection of latex beads into the central cornea stimulated LC migration to the corneal centre and subsequent grafting into these corneas led to a rejection rate of $98 \%$ instead of the normal $55 \%$. Depletion of LCs in the corneal bed prior to transplantation could possibly be a way of obtaining better graft survival in man. Following transplantation, this effect is already used by clinicians: application of corticosteroids leads to lower numbers of LCs in the cornea and a decrease in their antigen-presenting capacity. ${ }^{12,15}$ Good surgery with careful trephination and buried knots will probably contribute to the prevention of influx of LCs into the cornea as well. ${ }^{16}$

\section{CORNEAL LANGERHANS CELLS AND HERPETIC INFECTION}

The presence of LCs in the central cornea influences local immune responses in the cornea as well as in the anterior chamber. This was demonstrated in an experimental model of herpes simplex infection in mice. Stromal keratitis in herpes simplex infection is probably mediated by a virus-specific $\mathrm{T}$ cell response. ${ }^{17}$ Since the presence of antigen-presenting cells is necessary for the development of a $\mathrm{T}$ cellmediated immune response, it was hypothesised that an abnormal presence of high numbers of LCs in the cornea would stimulate an increased local immune response. $^{18}$ To test this hypothesis, cautery was applied to the centre of the cornea in BALB/c mice. This treatment induces migration of LCs to the centre of the cornea. ${ }^{19}$ In normal eyes, snout infection with HSV-1 led to zosteriform spread of virus, with a low incidence of stromal keratitis. After cautery, however, mice developed keratitis more frequently, with a much greater severity and with an increased involvement of the iris. The higher incidence and severity of herpetic keratitis in corneas containing LCs in their centre was associated with an earlier onset of a T-cell-mediated response, which subsequently endangered the integrity of the eye. ${ }^{18}$ The normal cornea is able to protect itself to some degree from the vision-decreasing effect of an anti-viral local immune response. ${ }^{20}$ Specific immunosuppressive factors have recently been identified in the cornea (see below).

\section{INFLUENCE OF THE CORNEA ON THE ANTERIOR CHAMBER}

Many experimental studies have focused on the specific regulation of immune responses in the anterior chamber of the eye, where immunosuppressive factors were identified some time ago. An antigen placed in the anterior chamber will be presented to the immune system through Schlemm's canal and the bloodstream, and not through the lymphatic system. This results in a specific type of immune response with suppression of a systemic delayed type hypersensitivity (DTH) response, the development of a humoral response without complement-fixing antibodies and normal cytotoxic $\mathrm{T}$ cell responses. This phenomenon is called ACAID (anterior chamber associated immune deviation: ${ }^{21}$ see review by Streilein in this issue). For example, injection of murine P815 tumour cells into the anterior chamber of a mouse eye induced suppression of DTH as measured by an ear swelling assay. Such an induction of ACAID by P815 cells did not occur when tumour cells were injected into eyes that contained Langerhans cells in the corneal centre: $^{.22}$ the development of immunosuppression is then inhibited.

\section{FACTORS PRESENT IN THE ANTERIOR CHAMBER}

It has been shown that the presence of molecules in the fluid of the anterior chamber of the eye is 
necessary to obtain the ACAID phenomenon. The most important factor is probably TGF- $\beta$, a molecule that can modulate a wide variety of immune reactions. ${ }^{23,24}$ TGF- $\beta$ is produced by iris and ciliary body cells. $^{25,26}$ It was recently shown that ACAID can even be induced in vivo by systemic injection of antigen-presenting cells that have been incubated with antigen and aqueous or TGF- $\beta$ in vitro. ${ }^{27,28}$ However, since inflammation in the eye inhibits the development of ACAID, it was tested whether inflammation-related cytokines were able to inhibit the in vitro ACAID-promoting activity of TGF- $\beta .^{29}$ Both IL-1 $\beta$ and IFN $\gamma$ were able to antagonise the ACAID-inducing effect of TGF- $\beta$.

The aqueous humour does not only modulate antigen presentation, but in itself has an immunosuppressive effect. Aqueous humour can inhibit mitogen (LPS, PHA and Con A) and allo-antigen driven T cell proliferation in vitro. ${ }^{30.31}$ In vitro cultures of murine iris and ciliary body cells (I-CB) were established ${ }^{32}$ and supernatants were harvested and assayed for their in vitro ability to inhibit $\mathrm{T}$ lymphocyte activation. Murine I-CB cell-derived supernatants were able to suppress allo-antigen driven $T$ cell proliferation in a mixed leucocyte reaction (MLR) and inhibited IL-2 production by a T cell hybridoma. The inhibitory factor in this case has not been identified, but is neither TGF- $\beta$ nor prostaglandin. Other factors may be identified as well. Knisely et $a l .{ }^{33}$ reported that the aqueous humour contained biologically relevant concentrations of glucocorticoids and that cortisol-binding globulin is relatively absent so that glucocorticoids are largely unbound. Variations in the level of these molecules in different diseases need to be studied, since they may play a critical role in the immunological equilibrium.

\section{EXPERIMENTAL WORK ON THE PRODUCTION OF SUPPRESSIVE FACTORS IN THE CORNEA}

\section{Introduction}

In addition to the presence of LCs in the cornea, other factors may determine whether or not an immune response will take place in the cornea. Sano and Streilein ${ }^{34}$ noticed that not only murine I-CB cells but also a normal murine cornea that is kept in culture produced factors that suppressed a murine MLR. Sano and Streilein subsequently tested which treatment modalities that are known to change the corneal environment were able to influence the production of the MLR suppressive factor: both cauterisation and a corneal incision were able to interfere with the production of immunosuppressive factors. We hypothesised that the pathological changes in the human cornea brought on by disease might interfere with the local production of such factors as well. We therefore obtained normal donor corneas and corneas from eyes undergoing corneal transplantation and tested whether the supernatant of such corneas was able to inhibit the murine MLR.

\section{Materials and Methods}

Test System for Corneal Suppressive Factor(s). A murine MLR consisting of spleen cells obtained from $\mathrm{BALB} / \mathrm{c}$ and $\mathrm{C} 57 \mathrm{~B} 1 / 6$ mice was used as test system. The two strains differ at the major histocompatibility complex and at numerous minor histocompatibility loci. BALB/c responder spleen cells $\left(2 \times 10^{5}\right.$ cells per well) were cultured with irradiated (2000 cGy) C57B1/6 stimulator cells $\left(2 \times 10^{5}\right.$ spleen cells per well). Cell proliferation was measured by tritiated thymidine incorporation. Supernatants from cultured cornea explants were added to some of the wells of the murine MLR. Since not all samples were tested in the same experiment, a comparison was made of the results expressed as a percentage of the score of the positive control (BALB/c as responder and C57B1/B6 as stimulator) in each experiment (example in Table I).

Preparation of Corneas. Human corneas were obtained from the Florida Lions Eye Bank, Miami, and cut in half for culturing in a 48 -well plate in 0.5 $\mathrm{ml}$ of conditioned RPMI culture medium. Patient corneas were obtained from the Bascom Palmer Eye Institute at the time of corneal transplantation. Supernatants to be tested were harvested 72 hours after the culture medium was last changed.

\section{Results}

Suppression of an MLR by the Supernatant of Cultured Human Corneas. Supernatants from corneal tissue were consistently immunosuppressive in this assay: corneal explants obtained from six normal eyes showed considerable variation (range 26-81\% immunosuppression, mean $60 \%$, SEM $7.8 \%$ ). Scleral tissue, on the other hand, did not cause any immunosuppression at all.

We wondered whether there was any difference in the production of suppressive factors between the corneal centre and the periphery, which normally does contain Langerhans cells as APCs. While the central cornea induced immunosuppression, the peripheral cornea did not, and even stimulated the MLR slightly (see Table I). We conclude that not only murine but also human corneal tissue produces immunosuppressive factors when cultured in vitro, and that with regard to the cornea there is a differential effect between the centre and the periphery. Further studies showed that the factor involved is neither prostaglandin nor TGF- $\beta{ }^{35}$

Immunosuppression by Diseased Corneal Tissue. Tissue obtained from the central cornea produced (an) immunosuppressive factor(s), while tissue from the peripheral cornea did not. We therefore 
Table I. Suppression of a murine MLR by supernatant (SN) from cultured human central cornea. peripheral cornea and sclera

\begin{tabular}{|c|c|c|c|c|c|}
\hline Responder & Stimulator & Supernatant & c.p.m. & $\pm \mathrm{SEM}$ & $\%$ suppression \\
\hline BALB/c & - & - & 876 & 101 & \\
\hline BALB/c & X-BALB/c & - & 989 & 8.5 & \\
\hline BALB/c & X-B6 & - & $110(07$ & 342 & \\
\hline $\mathrm{BALB} / \mathrm{c}$ & X-B6 & Central cornea & 61.32 & 197 & 45 \\
\hline $\mathrm{BALB} / \mathrm{c}$ & X-B6 & Limbal cornea & 149.34 & 617 & \\
\hline $\mathrm{BALB} / \mathrm{c}$ & X-B6 & Sclera & 11769 & 410 & \\
\hline
\end{tabular}

c.p.m., counts per minute; SEM, standard error of the mean: $X$. irradiated.

hypothesised that inflamed or vascularised corneas containing APCs ${ }^{12,36,37}$ or vessels would not produce any immunosuppressive factors, and would resemble peripheral corneal tissue. We were able to obtain corneal tissue from 18 eyes with bullous keratopathy and one with keratoconus, with different amounts of vessel ingrowth. The level of inhibition of the MLR varied from $29 \%$ to $83 \%$, with a mean of $65 \%$. This was not significantly different from the amount of immunosuppression induced with the supernatant from normal corneas ( $n=6$, average MLR inhibition $60 \%$ ). There was no significant correlation between the extent of immunosuppression induced by pathological corneas and the amount of corneal vessel ingrowth prior to transplantation $(p=0.2)$.

\section{IMMUNOSUPPRESSIVE FACTORS PRODUCED BY DIFFERENT LAYERS OF THE CORNEA: LITERATURE}

Little is known about the nature of corneal immunosuppressive factors, but others have shown that several different layers of the cornea are able to make immunosuppressive factors. Although the iris is supposed to be the main source of TGF- $\beta$, some TGF- $\beta$ is produced by the cornea. ${ }^{38}$ However, often the nature of the factor is not known, and is not TGF- $\beta$ or prostaglandin.

Originally, experiments were set up to test whether corneal cells obtained from the stroma were able to function as allo-antigen presenting cells and could stimulate proliferation of allogeneic lymphocytes. It was noticed that even after pre-treatment with interferon- $\gamma$, human corneal fibroblasts induced only minimal lymphocyte proliferation. The effect was really the opposite of what had been expected. In addition, co-cultivation of human corneal fibroblasts with peripheral blood leucocytes (PBLs) in the presence of Con A or PHA inhibited mitogeninduced lymphocyte proliferation by $40-90 \% .{ }^{31}$ The inhibition could be partly reversed by addition of indomethacin. Young and Stark ${ }^{40}$ had performed a similar study and compared the inhibitory effect of HLA-DR-positive and -negative human corneal fibroblasts. Although DR-positive cells were expected to stimulate an immune response, this was not the case: both DR-positive and DR-negative fibroblasts inhibited $\mathrm{T}$ cell proliferation in a third party mixed leucocyte response.

Recently, several articles describing this phenomenon and the elusive factor have been published. According to Donnelly et $\mathrm{al}^{41}$ the immunosuppressive effect of human corneal fibroblasts on the MLR of two unrelated third party cells depended on the continuous presence of the cells and their continuous production of a soluble inhibitory factor. Addition of interferon- $\gamma$ increased the inhibitory effect, while indomethacin had no effect, indicating that prostaglandins are not involved in this model.

Shams et al. ${ }^{42}$ working with another corneal layer, i.e. epithelium obtained from human corneo-scleralconjunctival rims, observed that the immunosuppressive factor worked across species barriers. A differential effect was observed between paraformaldehyde-fixed and unfixed cells: while fixed cells could still inhibit $\mathrm{T}$ cells by direct cell-cell contact, their supernatant no longer had an immunosuppressive effect. Only unfixed cells produced the suppressive soluble factor, which could be inhibited by addition of indomethacin.

The third corneal layer, the endothelium, was studied extensively by Gregerson and coworkers. They have reported that monolayers of LEW rat corneal endothelial (CE) cells inhibit in vitro $\mathrm{T}$ lymphocyte proliferation and IL-2 production in response to antigen or the mitogen Con $A .^{43-47}$ This phenomenon was observed using several rat and murine CD4 $\mathrm{T}$ cell lines, several $\mathrm{T}$ cell hybridomas and fresh rat lymphocytes. Initial studies showed that the inhibition of $\mathrm{T}$ cell proliferation by $\mathrm{CE}$ cells is neither MHC-restricted nor species-specific, since LEW rat CE cells inhibited both rat and murine $\mathrm{T}$ cells. Furthermore, rabbit, cat and human CE cells also inhibited both rat and murine T cells. ${ }^{+3.44}$ Induction of MHC class II expression on the CE cells by IFN- $\gamma$ did not affect their inhibitory activity, nor did it allow them to stimulate antigen-specific IL-2 production by several $\mathrm{T}$ cell hybridomas. ${ }^{+3.46}$ Although the activity has not yet been identified, the inhibition was not suppressed by indomethacin, suggesting that it is not prostaglandin $\mathrm{E}$. The inability of neutralising antibodies to TGF- $\beta 1$ and TGF- $\beta 2$ to reverse the inhibition suggests that the activity is not TGF- $\beta .^{45}$

That the inhibitory effect of the CE cells is not due 
to lack of TCR occupancy is supported by several observations. First, antigen-specific growth inhibition of $\mathrm{T}$ cell hybridomas was not affected by the presence of CE cells, showing that receptor occupancy occurs in the presence of CE cells. ${ }^{46}$ However, IL-2 production in the same cultures was inhibited. Second, stimulation of lymphocytes with antigen and antigen-presenting cells leads to upregulation of the IL-2R $\alpha$ chain in both the presence and absence of CE cells. ${ }^{46,47}$ Furthermore, the $\mathrm{T}$ cells are then responsive to exogenous IL-2 in the presence of CE cells, even though they produce little IL- $2 .{ }^{45}$ The proliferation of preactivated $\mathrm{T}$ cells subsequently transferred onto CE cells was not inhibited. ${ }^{45} \mathrm{~T}$ cells recovered from $\mathrm{CE}$ cell monolayers proliferate in response to conventional stimulation by antigen and antigen-presenting cells, and produce normal amounts of IL-2, showing that the effect is reversible $^{45}$ The results suggest that CE cells inhibit a step in signal transduction proximal to TCR occupancy, particularly given the dissociation between IL-2 production and growth inhibition/IL-2R $\alpha$ expression. Once activated, the lymphocytes are no longer susceptible to the inhibitory activity.

The nature of the inhibitory activity is currently unclear. Cell-free $\mathrm{CE}$ cell conditioned medium has some ability to inhibit lympho-proliferation assays, but it is much less potent than direct contact with the CE cells. Stronger inhibition is found in split-well assays, but it is also less potent than direct contact between $\mathrm{CE}$ cells and lymphocytes. Attempts to enrich or purify the activity by several approaches have been unsuccessful to date. These findings provide evidence for a potentially important and previously undescribed mechanism by which a tissue may regulate local immune responses.

To complicate matters, Shams et al. ${ }^{48}$ recently reported contradictory results: addition of corneal cells to an MLR led to a slight but significant increase in the proliferation of peripheral blood leucocytes. The cells in Shams' test system were obtained from corneo-scleral-conjunctival rims, and the corneal cells probably stimulated production of IL-1 $\beta$ by the peripheral blood leucocytes. Whether corneal cells induce suppression or stimulation may therefore depend on the source of the tissue (central or peripheral cornea), the test system used and probably a wide range of factors that will be discovered in the future.

\section{CONCLUSION}

It is likely that different molecules including TGF- $\beta$, indomethacin and potentially several other corneaderived factors or activities may be responsible for the immunosuppressive effect in different test systems and produced by different tissues around the anterior chamber of the eye. Even under pathological conditions some of these factors continue to be produced and can influence the topical immune responses. Further studies are necessary to identify the relevant factors and the means by which they regulate the local environment, in order that corneal graft survival in high-risk cases can be improved to the excellent level observed in low-risk corneal transplantations.

Part of this work was performed at the Department of Microbiology and Immunology, University of Miami, and the Department of Ophthalmology, Bascom Palmer Eye Institute, University of Miami, Miami, Florida, USA. Dr Jager is the recipient of a fellowship from the Royal Netherlands Academy of the Arts and Sciences. Dr Gregerson's work was supported by NIH grant EY 09207. Dr Streilein's work was supported by NIH grant EY 05678.

Key words: Aqueous, Cornea, Cytokines, Immunosuppression, TGF- $\beta$.

\section{REFERENCES}

1. Medawar PB. Immunity to homologous grafted skin. III. The fate of skin homografts transplanted to the brain, to subcutaneous tissue, and to the anterior chamber of the eye. Br J Exp Pathol 1948;29:58-67.

2. Niederkorn JY, Peeler JS. Regional differences in immune regulation: the immunogenic privilege of corneal allografts. Immunol Res 1988;7:247-55.

3. Katami M, Graudenz MS, White DJG, Watson PG. The role of antigen-presenting cells in rat corneal graft rejection. Transplant Proc 1991;23:93-5.

4. Callanan D, Peeler J, Niederkorn JY. Characteristics of rejection of orthotopic corneal allografts in the rat. Transplantation 1988;45:437-43.

5. Völker-Dieben J, D'Amaro J, Kok-van Alphen CC. Hierarchy of prognostic factors for corneal allograft survival. Aust NZ J Ophthalmol 1987;15:11-8.

6. Jager MJ, Hermans LJA, Dake CL, Gortzak-Moorstein N, Kok JHC, D'Amaro J. Follow-up of corneal transplantations at the Academic Medical Centre of Amsterdam. Doc Ophthalmol 1988;70:137-44.

7. Williams KA, Roder D, Esterman A, Muehlberg SM, Coster DJ. Factors predictive of corneal graft survival: report from the Australian Corneal Graft Registry. Ophthalmology 1992;99:403-14.

8. Völker-Dieben HJ, D'Amaro J, Kruit PJ, Lange P de. Interaction between prognostic factors for corneal allograft survival. Transplant Proc 1989;21:3135-8.

9. Khodadoust AA, Silverstein AM. Studies on the nature of the privilege enjoyed by corneal allografts. Invest Ophthalmol 1972;11:137-48.

10. Williams KA, Coster DJ. Penetrating corneal transplantation in the inbred rat: a new model. Invest Ophthalmol Vis Sci 1985;26:23-30.

11. Jager MJ. Corneal Langerhans cells and ocular immunology. Reg Immunol 1992;4:186-95.

12. Gillette TE, Chandler JW, Greiner JV. Langerhans cells of the ocular surface. Ophthalmology 1982;89:700-11.

13. Delbosc B, Fellmann D, Piquot X, Montard M, Royer J. Antigenicité HLA des cornées humaines normales et pathologiques. J Fr Ophtalmol 1990;13:535-41.

14. Niederkorn JY, Peeler JS, Ross J, Callanan D. The 
immunogenic privilege of corneal allografts. Reg Immunol 1989;2:117-24.

15. Berman B, France DS, Martinelli GP, Hass A. Modulation of expression of epidermal Langerhans cell properties following in situ exposure to glucocorticosteroids. J Invest Dermatol 1983;80:168-71.

16. Lang RM, Friedlaender MH, Schoenrock BJ. A new morphologic manifestation of Langerhans cells in guinea pig corneal transplants. Curr Eye Res 1981;1:161-7.

17. Russell RG, Nasise MP, Larsen HS, Rouse BT. Role of T-lymphocytes in the pathogenesis of herpetic stromal keratitis. Invest Ophthalmol Vis Sci 1984;25:938-44.

18. McLeish W, Rubsamen P, Atherton SA, Streilein JW. Immunobiology of Langerhans cells on the ocular surface. II. Role of central corneal Langerhans cells in stromal keratitis following experimental HSV-1 infection in mice. Reg Immunol 1989;2:236-43.

19. Kamenar T, Asbell PA. The effect of thermal burns on Langerhans cells and herpes keratitis. Invest Ophthalmol Vis Sci 1988;29(Suppl):433.

20. Jager MJ, Atherton S, Bradley D, Streilein JW. Role of corneal Langerhans cells in the development of herpetic stromal keratitis in mice. Curr Eye Res 1991;10(Suppl):69-73.

21. Streilein JW. Anterior chamber associated immune deviation: the privilege of immunity in the eye. Surv Ophthalmol 1990;35:67-73.

22. Williamson JSP, DiMarco S, Streilein JW. Immunobiology of Langerhans cells on the ocular surface. I. Langerhans cells within the central cornea interfere with induction of anterior chamber associated immune deviation. Invest Ophthalmol Vis Sci 1987;28:1527-32.

23. Granstein RD, Staszewski R, Knisely TL, Zeira E, Nazareno R, Latina M, Albert DM. Aqueous humour contains transforming growth factor- $\beta$ and a small (<3500 daltons) inhibitor of thymocyte proliferation. J Immunol 1990;144:3021-7.

24. Fontana A, Constam DB, Frei K, Malipiero U, Pfister HW. Modulation of the immune response by transforming growth factor beta. Int Arch Allergy Immunol 1992;99:1-7.

25. Helbig H, Kittredge KL, Coca-Prados M, Davis J, Palestine AG, Nussenblatt RB. Mammalian ciliarybody epithelial cells in culture produce transforming growth factor-beta. Graefe's Arch Clin Exp Ophthalmol 1991;229:84-7.

26. Knisely TL, Bleicher PA, Vibbard CA, Granstein RD. Production of latent transforming growth factor-beta and other inhibitory factors by cultured murine iris and ciliary body cells. Curr Eye Res 1991;10:761-71.

27. Wilbanks GA, Streilein JW. Suppression of delayed hypersensitivity in vivo by an ACAID-inducing signal created in vitro. Invest Ophthalmol Vis Sci 1992;33(Suppl):1283.

28. Wilbanks GA, Streilein JW. Fluids from immune privileged sites endow macrophages with the capacity to induce antigen-specific immune deviation via a mechanism involving transforming growth factor-beta. Eur J Immunol 1992;22:1031-6.

29. Okamoto S, Streilein JW. ACAID-inhibiting properties of selected pro-inflammatory factors (abs. JERMOV 1994 , p. 194).

30. BenEzra D, Sachs U. Growth factors in aqueous humour of normal and inflamed eyes of rabbits. Invest Ophthalmol Vis Sci 1973;13:868-70.

31. Kaiser CJ, Ksander BR, Streilein JW. Inhibition of lymphocyte proliferation by aqueous humour. Reg Immunol 1989;2:42-9.
32. Streilein JW, Bradley D. Analysis of immunosuppressive properties of iris and ciliary body cells and their secretory products. Invest Ophthalmol Vis Sci 1991;32:2700-10.

33. Knisely TL, Hosoi J, Nazareno R, Granstein RD. The presence of biologically significant concentrations of glucocorticoids but little or no cortisol binding globulin within aqueous humour: relevance to immune privilege in the anterior chamber of the eye. Invest Ophthalmol Vis Sci 1994;35:3711-23.

34. Sano Y, Streilein JW. Effects of corneal surgical wounds on ocular immune privilege. In Nussenblatt RB et al., eds. Advances in ocular immunology. Amsterdam: Elsevier, 1994;207-10.

35. Jager MJ, Bradley D, Streilein JW. Immunosuppressive properties of human cornea and iris/ciliary body in normal and pathological conditions. Transplant Immunol 1995; (in press).

36. Williams KA, Ash JK, Coster DJ. Histocompatibility antigen and passenger cell content of normal and diseased human cornea. Transplantation 1985;39:265-9.

37. Williams KA, White MA, Ash JK, Coster DJ. Leukocytes in the graft bed are associated with corneal graft failure: analysis by immunohistology and actuarial graft survival. Ophthalmology 1989;96:38-44.

38. Wilson SE, Lloyd SA. Epidermal growth factor, transforming growth factor beta-1, and interleukin-1a messenger RNA production in human corneal endothelial cells. Invest Ophthalmol Vis Sci 1991;32:2747-56.

39. Donnelly JJ, Chan LS, Xi M-S, Rockey JH. Effect of human corneal fibroblasts on lymphocyte proliferation in vitro. Exp Eye Res 1988;47:61-70.

40. Young E, Stark WJ. In vitro immunological function of human corneal fibroblasts. Invest Ophthalmol Vis Sci 1988;29:1402-6.

41. Donnelly JJ, Zi MS, Rockey JH. A soluble product of human corneal fibroblasts inhibits lymphocyte activation: enhancement by interferon-gamma. Exp Eye Res 1993;56:157-65.

42. Shams NBK, Huggins EM, Sigel MM. Regulation of mitogen-driven lymphoreticular cell activation by human corneal cells and interleukin-1. Cornea 1993;12:46-53.

43. Obritsch WF, Kawashima H, Evangelista A, Ketcham $\mathrm{JM}$, Holland EJ, Gregerson DS. Inhibition of in vitro $\mathrm{T}$ cell activation by corneal endothelial cells. Cell Immunol 1992;144:80-94.

44. Kawashima H, Obritsch WF, Gregerson DS. Corneal endothelial cells create and maintain a unique microenvironment for immune cells. Reg Immunol, in press.

45. Kawashima H, Gregerson DS. Corneal endothelial cells block $\mathrm{T}$ cell proliferation, but not $\mathrm{T}$ cell activation or responsiveness to exogenous IL-2. Curr Eye Res 1994;13:575-85.

46. Kawashima H, Prasad SA, Gregerson DS. Corneal endothelial cells inhibit $\mathrm{T}$ cell proliferation by blocking IL-2 production. J Immunol 1994;153:1982-9.

47. Kawashima H, Gregerson DS. Corneal endothelial cells block IL-2 production, but not IL-2 receptor upregulation of $\mathrm{T}$ cells. In Nussenblatt RB et al., eds. Advances in ocular immunology. Amsterdam: Elsevier, 1994;11-15.

48. Shams NBK, Huggins EM, Sigel MM. Interleukin-1 regulates the proliferation of leucocytes in human corneal cell-peripheral blood leukocyte cocultures. Cornea 1994;13:9-15. 